\title{
MicroRNAs Regulate Human Brain Endothelial Cell-Barrier Function in Inflammation: Implications for Multiple Sclerosis
}

\author{
Arie Reijerkerk, ${ }^{1 \star}$ M. Alejandro Lopez-Ramirez, ${ }^{2 *}$ Bert van het Hof, ${ }^{1}$ Joost A.R. Drexhage, ${ }^{1}$ Wouter W. Kamphuis, ${ }^{1}$ \\ Gijs Kooij, ${ }^{1}$ Joost B. Vos, ${ }^{3}$ Tineke C.T.M. van der Pouw Kraan, ${ }^{3}$ Anton J. van Zonneveld, ${ }^{4}$ Anton J. Horrevoets, ${ }^{3}$ \\ Alexandre Prat, ${ }^{5}$ Ignacio A. Romero, ${ }^{\dagger \dagger}$ and Helga E. de Vries ${ }^{1 \dagger}$ \\ ${ }^{1}$ Blood-Brain Barrier Research Group, Molecular Cell Biology and Immunology, Neuroscience Campus Amsterdam, VU University Medical Center, 1007 \\ MB Amsterdam, The Netherlands, ${ }^{2}$ Department of Life, Health \& Chemical Sciences, The Open University, Milton Keynes MK7 6AA, United Kingdom, \\ ${ }^{3}$ Molecular Cell Biology and Immunology, VU University Medical Center, 1007 MB Amsterdam, The Netherlands, ${ }^{4}$ Department of Nephrology and \\ Einthoven Laboratory for Experimental Vascular Research, Leiden University Medical Center, 2333 ZA Leiden, The Netherlands, and ${ }^{5} \mathrm{Neuroimmunology}$ \\ Research Laboratory, Centre of Excellence in Neuromics, CHUM-Notre-Dame Hospital, Faculty of Medicine, Université de Montréal, Montréal, Quebec H2L \\ 4M1, Canada
}

Blood-brain barrier (BBB) dysfunction is a major hallmark of many neurological diseases, including multiple sclerosis (MS). Using a genomics approach, we defined a microRNA signature that is diminished at the BBB of MS patients. In particular, miR-125a-5p is a key regulator of brain endothelial tightness and immune cell efflux. Our findings suggest that repair of a disturbed BBB through microRNAs may represent a novel avenue for effective treatment of MS.

\begin{abstract}
Introduction
The blood-brain barrier (BBB) tightly controls the homeostasis of the CNS and actively limits entry of blood-borne molecules and circulating leukocytes. In essence, the BBB is formed by specialized endothelial cells sealed together by intercellular tight junction protein complexes. Although mature astrocytes are not needed for BBB induction (Daneman et al., 2010), these cells are essential in the maintenance of the barrier function through the release of soluble mediators (Abbott et al., 2006; Alvarez et al., 2011). Disruption and immune activation of the $\mathrm{BBB}$ are central and early features of multiple sclerosis (MS), a chronic inflammatory disorder of the CNS (Neuwelt et al., 2008, 2011; Zlokovic, 2008). Compromised function of the $\mathrm{BBB}$ is also a key early event in the pathogenesis of several neurodegenerative disorders with an inflammatory compo-
\end{abstract}

Received Aug. 20, 2012; revised Feb. 18, 2013; accepted Feb. 27, 2013.

Author contributions: A.R., I.A.R., and H.E.d.V. designed research; A.R., M.A.L.-R., B.v.h.H., J.A.R.D., W.K., G.K., and J.B.V. performed research; A.P. contributed unpublished reagents/analytic tools; A.R., M.A.L.-R., J.B.V., T.C.T.M.v.d.P.K., A.J.v.Z., and A.J.H. analyzed data; A.R. and H.E.d.V. wrote the paper.

This work was supported by grants from the Netherlands Genomics Initiative (A.R., J.A.R.D.), the MS Research Foundation (A.R. and H.E.d.V., Grant 08-642), ZonMw [J.B.V.; DPTE (Dutch Program Tissue Engineering) Grant LGT.6918], and Multiple Sclerosis Society of Great Britain and Northern Ireland (I.A.R.). The funders had no role in study design, data collection, and analysis; decision to publish; or preparation of the manuscript.

The authors declare no competing financial interests.

*A.R. and M.A.L.-R. contributed equally to this work.

${ }^{\dagger}$ I.A.R. and H.E.d.V. contributed equally to this work.

Correspondence should be addressed to either of the following: Helga E. de Vries, Blood-Brain Barrier Research Group, Molecular Cell Biology and Immunology, VU University Medical Center, PO Box 7057, 1007 MB Amsterdam, The Netherlands, E-mail: he.devries@vumc.nl; or Ignacio A. Romero, Department of Life, Health \& Chemical Sciences, The Open University, Milton Keynes MK76AA, United Kingdom. E-mail: i.romero@open.ac.uk.

DOI:10.1523/JNEUROSCI.3965-12.2013

Copyright $\odot 2013$ the authors $\quad 0270-6474 / 13 / 336857-07 \$ 15.00 / 0$ nent, such as Alzheimer's disease and Parkinson's disease. Proinflammatory cytokines, such as TNF $\alpha$ and IFN $\gamma$ secreted by activated leukocytes and/or CNS-resident cells, are considered to mediate changes in gene expression in brain endothelial cells toward an "inflamed " phenotype. Indeed, increased permeability and expression of cell-adhesion molecules on the brain endothelium allow the trafficking of inflammatory agents and circulating leukocytes into the CNS, leading to demyelination and axonal loss (Lassmann et al., 2007; Larochelle et al., 2011). An understanding of the underlying mechanisms of barrier disruption in MS may lead to the development of novel and selective routes of intervention to prevent the influx of inflammatory cells into the CNS.

MicroRNAs, which are endogenous noncoding small RNAs, are now recognized to play a critical role in key cellular functions by specifically repressing gene expression (Filipowicz et al., 2008). Importantly, altered microRNA expression levels have been demonstrated in a number of CNS pathologies, including brain tumors, neurodegeneration, and MS (Hébert and De Strooper, 2009; O'Connell et al., 2010; Junker et al., 2011; Smits et al., 2012). Several microRNAs have been identified in endothelial cells and they have been implicated in primary endothelial cell function and angiogenesis (for review, see Suárez and Sessa, 2009; Bonauer et al., 2010). Thus far, it is not known whether microRNAs play a role in BBB function, which was hypothesized in the current study. Our novel data show that a set of microRNAs modulates BBB function under normal and inflammatory conditions. Most importantly, levels of BBBassociated microRNAs were diminished in isolated MS patient capillaries. Together, our findings uncover an unprecedented and 
exciting regulatory mechanism of brain endothelial cell barrier function in health and disease and provide novel opportunities to treat neurovascular-dependent brain diseases through microRNAs.

\section{Materials and Methods}

Cells, cell culture, and materials. The human cerebral microvascular endothelial cell line hCMEC/D3 (Weksler et al., 2005) was grown in Endothelial Cell Basal Medium-2 (EGM-2, Lonza) supplemented with human EGF, hydrocortisone, GA-1000, FBS, VEGF, human fibroblast growth factor-B, R3-IGF-1, ascorbic acid, and 2.5\% fetal calf serum. To obtain astrocyte cultures, fetal tissue (cerebral hemispheres) was obtained at 17-23 weeks of gestation following Canadian Institute of Health Research-approved guidelines. Human fetal astrocytes were used between postnatal days 2 and 4 , and cultures were determined to be $>90 \%$ pure, as determined by GFAP immunostaining. Astrocyte-conditioned media (ACM) was harvested once a week from confluent flasks of human fetal astrocyte cultures. Anti-vascular endothelial-cadherin (anti-VEcadherin; clone F8) was from Santa Cruz Biotechnology. The tight junction protein zona occludens-1 was stained with rabbit anti-zona occludens-1 from Zymed. Secondary antibodies Alexa Fluor 488 goat anti-rabbit IgG and Alexa Fluor 555 goat anti-mouse IgG were from Invitrogen.

MicroRNA profiling of inflamed brain endothelial cells. Human brain endothelial (hCMEC/D3) cells were grown on collagen-coated six-well plate tissue culture until confluence and then maintained for $72 \mathrm{~h}$. Subsequently, culture media was changed to EGM-2 with all the supplements mentioned above with the exception of VEGF. After stimulation with TNF $\alpha$ and IFN $\gamma$ using $10 \mathrm{ng} / \mathrm{ml}$ for $24 \mathrm{~h}$, cells were washed once with prewarmed HBSS. Total RNA was extracted using miRNeasy Mini Kit (Qiagen) according to the manufacturer's protocols. The quantity (NanoDrop 1000 spectrophotometer) and the quality (2100 Bioanalyzer, RNA 6000 Pico LabChip; Agilent Technologies) were assessed for each sample. Total RNA (100 ng) was labeled with pCp-Cy3 using T4 RNA ligase (GE Healthcare) and the Agilent human microRNA microarray kit annotated in the Sanger miRbase (release 12.0) containing probes for 939 human microRNAs was performed according to the Agilent's microRNA microarray profiling. GeneSpring GX 9 software (Agilent Technologies) was used for value extraction. Statistical significance was determined by Student's $t$ test for each microRNA probe.

MicroRNA profiling of astrocyte-treated brain endothelial cells. For array analyses hCMEC/D3 cells were incubated with 50\% ACM in supplemented EGM-2 for $48 \mathrm{~h}$. Total RNA was isolated from all cell lysates. Before microRNA profiling, the RNA samples underwent quality control by Agilent Bioanalyzer Picochip analysis (RNA integrity number, $>9$ ). For microRNA expression analyses (Exiqon), $1 \mu \mathrm{g}$ of total RNA from sample and reference was labeled with Hy3 and Hy5 fluorescent label, respectively, using the miRCURY LNA Array power labeling kit (Exiqon) following the procedure described by the manufacturer. The Hy3-labeled samples and a Hy5-labeled reference RNA sample were mixed pairwise and hybridized to the miRCURY LNA array version 11.0 (Exiqon), which contains capture probes targeting all microRNAs for human, mouse, or rat registered in the miRBASE version 12.0 at the Sanger Institute. The hybridization was performed according to the miRCURY LNA array manual using a Tecan HS4800 hybridization station (Tecan). After hybridization, the microarray slides were scanned and stored in an ozonefree environment (ozone level, $<2.0 \mathrm{ppb}$ ) to prevent potential bleaching of the fluorescent dyes. The miRCURY LNA array microarray slides were scanned using the Agilent G2565BA Microarray Scanner System (Agilent Technologies) and the image analysis was performed using the ImaGene 8.0 software (BioDiscovery). Generation and statistical analysis of microRNA expression profiles were performed similarly using R/Bioconductor. Quantile normalization of intensities of individual spots was followed by reference color adjustment and ratios of probes representing the same microRNA were averaged. Differential expression of ACMtreated versus control samples was determined by Baysian statistics $t$ test (Baldi and Long, 2001) and multiple testing adjustment using Benjamini and Hochberg's method (Benjamini and Hochberg, 1995).
Isolation of MS capillaries. The tissues were obtained from The Netherlands Brain Bank (NBB), Netherlands Institute for Neuroscience, Amsterdam. For all material, NBB obtained from donors a written informed consent for brain autopsy and the use of the material and clinical information for research purposes. Brain capillaries were isolated from periventricular non-neurological patient tissue, periventricular normalappearing white matter, and periventricular MS lesions from postmortem MS patients. After resection, the tissues were homogenized using pestles and capillaries were separated from myelin and single cells using dietheylaminoethyl-dextran gradient (15\%; Sigma-Aldrich) centrifugation for $25 \mathrm{~min}$ at $2500 \mathrm{rpm}$ without brake. Isolated capillaries were washed on a $40 \mu \mathrm{m}$ meshed filter (BD Falcon) to remove red blood cells. Finally, RNA was extracted with Trizol and stored in $-80^{\circ} \mathrm{C}$. The capillaries were characterized by qPCR analysis of brain endothelial cell markers zona occludens-1, claudin-5, VE-cadherin, and P-glycoprotein; the pericyte marker platelet-derived growth factor receptor- $\beta$; and astrocyte marker GFAP $\alpha$.

qPCR analysis of microRNA expression. The Universal cDNA Synthesis Kit (Exiqon) was used for cDNA synthesis. Extracted RNA was diluted to $5 \mu \mathrm{g} / \mu \mathrm{l}$ using RNase-free water. For each reaction, $2 \mu \mathrm{l}$ of diluted RNA was added to a mixture of $2 \mu \mathrm{l}$ of $5 \times$ buffer, $4.5 \mu \mathrm{l}$ of RNase-free water, $1 \mu \mathrm{l}$ of enzyme mix, and $0.5 \mu \mathrm{l}$ of RNA spike-in. The samples were incubated at $42^{\circ} \mathrm{C}$ for $1 \mathrm{~h}$ followed by heat inactivation at $95^{\circ} \mathrm{C}$ for $5 \mathrm{~min}$. Samples were cooled to $4^{\circ} \mathrm{C}$ and stored at $-20^{\circ} \mathrm{C}$ thereafter. The qPCR was performed using the Pick-\&-Mix microRNA PCR Panel using the LNA microRNA PCR primer sets for the indicated 11 microRNAs (Exiqon). Three independent samples per plate were tested. The cDNA was diluted 1:100 in RNase-free water. Per well, $5 \mu$ l of sample and $5 \mu$ l of $2 \times$ SYBRgreen mastermix were added and plates were then sealed and centrifuged. qPCR was performed on an Applied Biosystems ViiA 7 machine for 40 cycles, which consisted of two steps at $95^{\circ} \mathrm{C}$ for $10 \mathrm{~s}$ and $60^{\circ} \mathrm{C}$ for 1 min. Specificity of the PCR product was determined by a melting curve at the end of the qPCR.

Lentiviral delivery of $m i R-125 a-5 p$. The miR-125a-5p sequence was obtained from the miR-Vec library (Voorhoeve et al., 2006) and ligated between the NdeI and EcoRI restriction sites of pRRL-cPPT-CMV-X2PRE-SIN-IRES-eGFP vector (kindly provided by Dr. J. Seppen, Department of Experimental Hepatology, Academic Medical Center, Amsterdam, The Netherlands). Recombinant lentiviruses were produced by cotransfecting subconfluent HEK293T cells with the specific expression plasmids and packaging plasmids (pMDLg/pRRE, pRSV-Rev, and pMD2G) using calcium phosphate as a transfection reagent. HEK293T cells were cultured in DMEM, supplemented with $10 \%$ FCS and $1 \%$ penicillin/streptomycin, in a $37^{\circ} \mathrm{C}$ incubator with $5 \% \mathrm{CO}_{2}$. Infectious lentiviruses were collected $48 \mathrm{~h}$ after transfection. The supernatant was centrifuged to remove cell debris and stored at $-80^{\circ} \mathrm{C}$. Overexpression efficiency in hCMEC/D3 cells was determined by qPCR.

Transfections. hCMEC/D3 cells were transfected using Amaxa Technology (Lonza). Per condition, $15 \mathrm{~cm}^{2}$ of $80-90 \%$ confluent cells were trypsinized and transfected with siRNA against miR-125a-5p (2.5 $\mu$ l of $25 \mu \mathrm{M}$ miRCURY LNA microRNA Inhibitor, Exiqon) or scrambled RNA ( $2.5 \mu \mathrm{l}$ of $25 \mu \mathrm{M}$ miRCURY LNA microRNA Inhibitor Negative Control, Exiqon). The transfection was performed with the 4D-Nucleofector System and P5 Primary Cell Solution Kit (Amaxa, Lonza), according to the manufacturer's protocol. After transfection, the cells were resuspended in RPMI-1640 medium supplemented with penicillin $(100 \mathrm{U} / \mathrm{ml})$ and streptomycin $(100 \mu \mathrm{g} / \mathrm{ml})$ for $5 \mathrm{~min}$, and subsequently seeded on collagen-coated electrical cell-substrate impedance-sensing (ECIS) arrays with additional supplemented EGM-2 medium. Knockdown of miR-125a-5p was assessed by qPCR.

ECIS assay. ECIS Model 1600R (Applied BioPhysics) was used to measure the transendothelial electric resistance of hCMEC/D3 cell monolayers in real time as described previously (Keese et al., 2004). We seeded 100,000 cells onto each well of an 8 W10 + ECIS array coated with collagen. Impedance was measured at $6000 \mathrm{~Hz}$ in real time. Cells were treated with a 1:1 mixture of ACM and EGM-2 containing 2.5\% FCS or with 10 $\mathrm{ng} / \mathrm{ml} \mathrm{TNF} \alpha$ and IFN $\gamma$ immediately after seeding. Lentiviral transduction of microRNA-125a was performed directly after seeding in the ECIS array. 
A

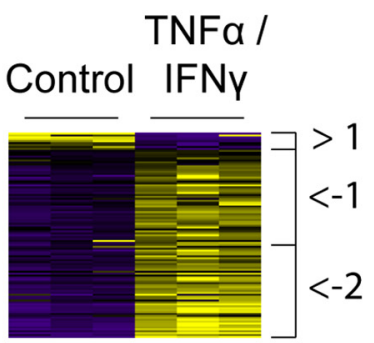

C
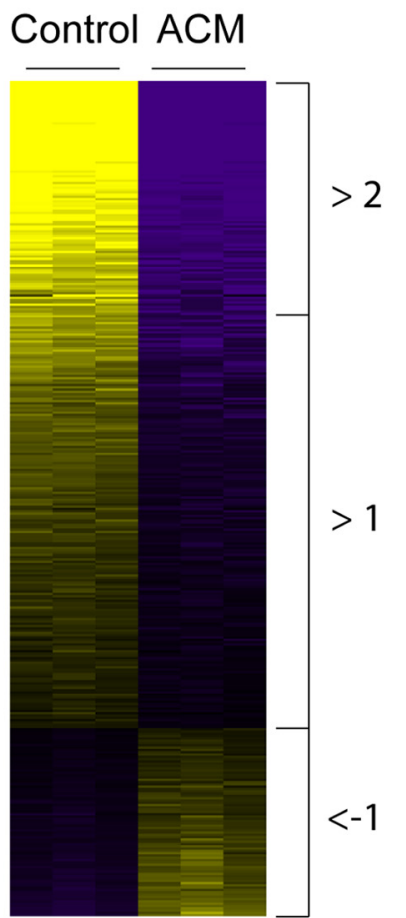

B
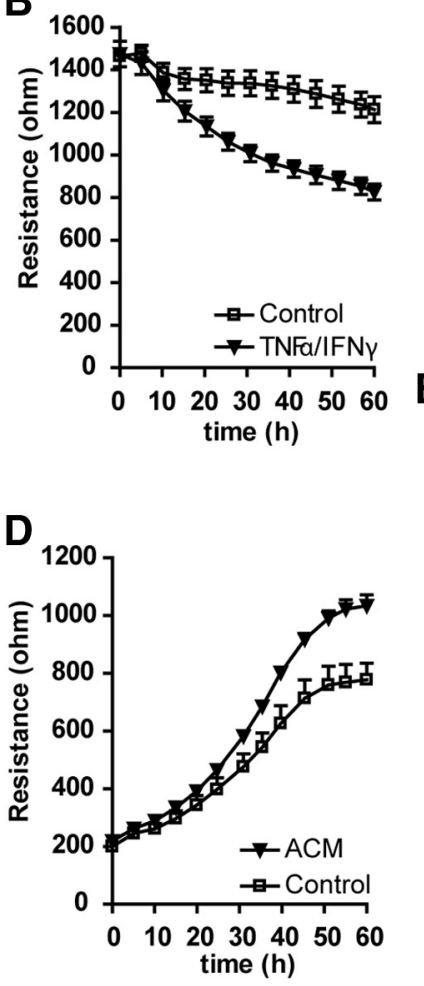

\section{E}

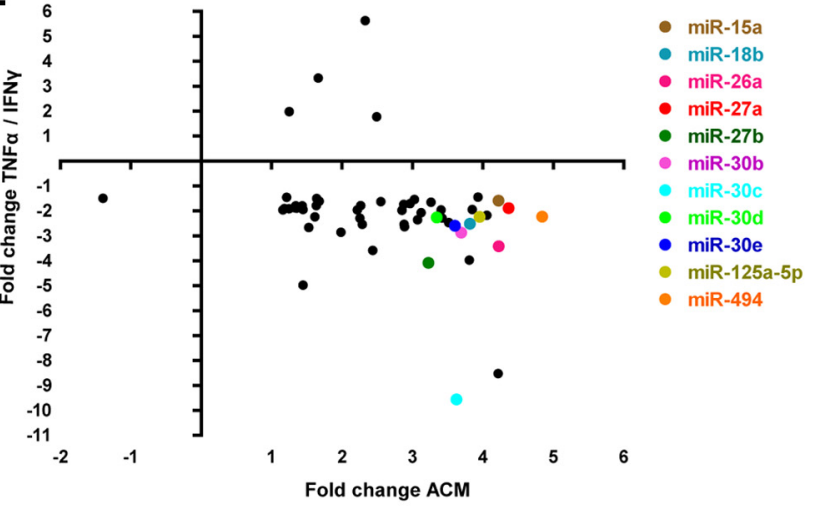

Figure 1. Brain endothelial microRNAs are deregulated in inflammation in vitro. $\boldsymbol{A}, \boldsymbol{C}$, Heat map of differential microRNA expression in $(\boldsymbol{A})$ TNF $\alpha$ and IFN $\gamma(10 \mathrm{ng} / \mathrm{ml}$ for $24 \mathrm{~h})$ and $(\boldsymbol{C})$ astrocyte factor-treated (ACM, 50\% v/v, $48 \mathrm{~h}$ ) hCMEC/D3 cells. Purple indicates relatively higher expressed microRNAs. Yellow indicates relatively lower expressed microRNAs. $\boldsymbol{B}$, ECIS analysis of control and TNF $\alpha /$ IFN $\gamma$-treated hCMEC/D3 cells. Maximal resistance in control: $1014 \pm 41.2 \Omega$; TNF $\alpha /$ IFN $\gamma$ : $667.6 \pm 41.2 \Omega, n=4, p=0.001$ by Student's $t$ test. $\boldsymbol{D}$, ECIS analysis of control and astrocyte-derived factor-treated hCMEC/D3 cells. Maximal resistance in control: $1673 \pm 1.1 \Omega ; A C M(50 \% \mathrm{v} / \mathrm{v}): 2008 \pm 58.8 \Omega, n=3, p=0.001$ by Student's $t$ test. Error bars represent the mean \pm SEM. $\boldsymbol{E}$, Representation of common microRNAs regulated after ACM and TNF $\alpha /$ IFN $\gamma$-treatment in hCMEC/D3 cells.

Statistical analysis. Statistical analysis was performed with the Student's $t$ test (Prism 4.0; GraphPad Software), and results were considered significant if $p$ was $<0.05$.

\section{Results}

Here we explored whether microRNAs control BBB function and its immunoquiescence in MS. First, microRNA expression profiling indicated that exposure of cultured brain endothelial cells to inflammatory mediators significantly changed the expression level of 107 microRNAs (Fig. 1A). Of note, most (98 of 107) of the differentially expressed microRNAs were downregulated by TNF $\alpha$ and IFN $\gamma$ treatment, which was also shown to impair barrier function (Fig. 1B). Next, as a means to identify barrierrelated microRNAs, we cultured brain endothelial cells in the presence of astrocyte-released factors. Continuous treatment of brain endothelial monolayers with conditioned media of cultured astrocytes for $48 \mathrm{~h}$ induced a tighter barrier in cultured brain endothelial cells (Fig. 1D) and significantly changed the expression level of 365 microRNAs (Fig. 1C). In this case, 278 of 365 of the differentially expressed microRNAs were increased in the brain endothelial cells by astrocyte-released factors, suggesting that microRNA-mediated induction of BBB properties is largely due to repression of protein synthesis within the brain endothelium. Remarkably, the overlay of the microRNA expression profiles between TNF $\alpha / \mathrm{IFN} \gamma$ (i.e., barrier-reducing) and astrocyte factor (i.e., barrier-inducing) treatments revealed that the expression of 50 of the 55 microRNAs regulated by both treatments changed in opposite directions. MicroRNAs decreased by barrier-reducing TNF $\alpha / \operatorname{IFN} \gamma$ treatment were enhanced by barrier-inducing astrocyte factors and vice versa (Fig. $1 E$ ). These data strongly suggest a potential and important function of a set of microRNAs controlling the balance between a tight and leaky or inflamed BBB.

To specifically identify microRNAs involved in the immuneactivated and dysfunctional BBB as observed in MS, we next assessed the expression level of this particular set of BBB-related microRNAs. Quantitative PCR analyses of 11 microRNAs with the highest differential in expression levels when comparing barrier-enhancing versus barrier-reducing stimuli (Fig. 1E, colored dots) was done using freshly isolated brain capillaries from MS lesion areas and normal-appearing white matter in MS patients (Fig. $2 A$, patient characteristics). Freshly isolated brain capillaries comprised brain endothelial cells as indicated by zona 
occludens-1, claudin-5, P-glycoprotein, and VE-cadherin expression and contained minor amounts of astrocytes (GFAP $\alpha$ and GFAP $\beta$ ) and pericytes (platelet-derived growth factor receptor- $\beta$ ) (Fig. $2 B$ ). Most strikingly, all the microRNAs selected according to their opposing regulation in $\mathrm{TNF} \alpha / \mathrm{IFN} \gamma$ and astrocyte factor-treated brain endothelial cells were reduced in brain capillaries in MS lesions (Fig. 2C). These findings indicate that the currently identified microRNAs may represent potential and novel mechanisms by which $\mathrm{BBB}$ function is altered in MS. Of note, it was reported before that miR-125a-5p in particular can regulate inflammatory processes (Chen et al., 2009; Li et al., 2010; Zhao et al., 2010). The decreased expression of miR-125a-5p in MS lesions was corroborated in brain endothelial cells obtained from normal-appearing white matter and active lesions of MS patients through a laser capture approach (Fig. 2D).

Normally, the barrier function of the brain endothelium is instigated by the presence of specific cell-cell junction complexes and a high endothelial resistance to paracellular trafficking of ions and other molecules. We therefore set out to assess the contribution of miR-125a-5p to the formation of a tight brain endothelial barrier. Using cell lines overexpressing miR-125a-5p, we determined that miR125a-5p significantly increased brain endothelial cell barrier function, thereby mimicking the function of astrocytes (Fig. $3 A)$. Conversely, specific knockdown of miR-125a-5p reduced the barrierenhancing effect of astrocytes without influencing barrier formation under control conditions (Fig. 3B). Subsequent confocal microscopy analyses revealed that cells with increased levels of miR-125a-5p formed thicker and more continuous junctional complexes of VE-cadherin and zona occludens-1, whereas the opposite was found in cells with reduced levels of miR-125a-5p (Fig. 2C). The altered expression levels of VE-cadherin was confirmed by Western blotting (data not shown).

In general, the brain endothelial cell barrier maintains immune quiescence of the brain through the low expression of adhesion molecules, such as intracellular cell adhesion molecule (ICAM)-1, a cell adhesion molecule involved in vascular permeability and leukocyte infiltration. However, under inflamed conditions, as apparent during MS, brain endothelial cells strongly upregulate cell adhesion molecules that in turn mediate the migration of leukocytes into the brain. Treatment of the brain endothelium with the proinflammatory mediators TNF $\alpha / \operatorname{IFN} \gamma$ caused a strong reduction of miR-125a-5p levels (Fig. 3D), which in turn was associated with enhanced expression of the endothelial cell adhesion molecule ICAM-1 and increased diapedesis of leukocytes (Fig. 2E,F). Interestingly, overexpression of miRpaired Student's $t$ test.
A

B

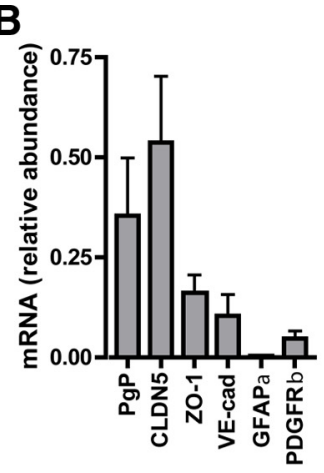

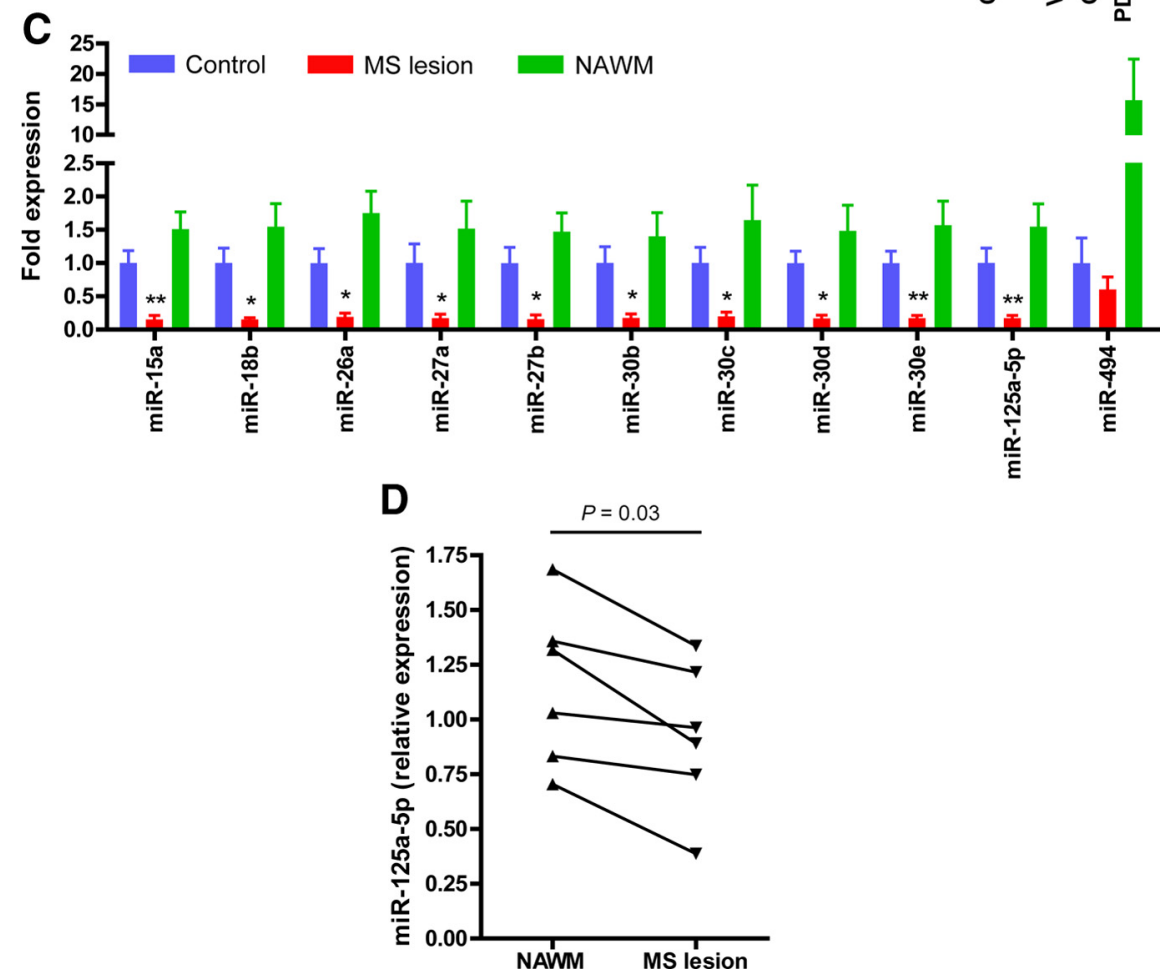

Figure 2. Brain endothelial microRNAs are deregulated in MS patients. $\boldsymbol{A}, \mathrm{MS}$ and non-neurological control patient characteristics. $\boldsymbol{B}$, Capillaries isolated from normal-appearing white matter were characterized for expression of brain endothelial cell markers zona occludens-1, claudin-5, VE-cadherin, and P-glycoprotein; the pericytes marker platelet-derived growth factor or- $\beta$; and astrocyte marker GFAP at the mRNA level by qPCR analysis. Data show the relative abundance of the (blue), MS patient normal-appearing white matter (NAWM, green), and MS lesions (red). Data

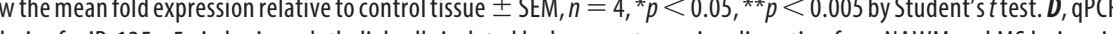
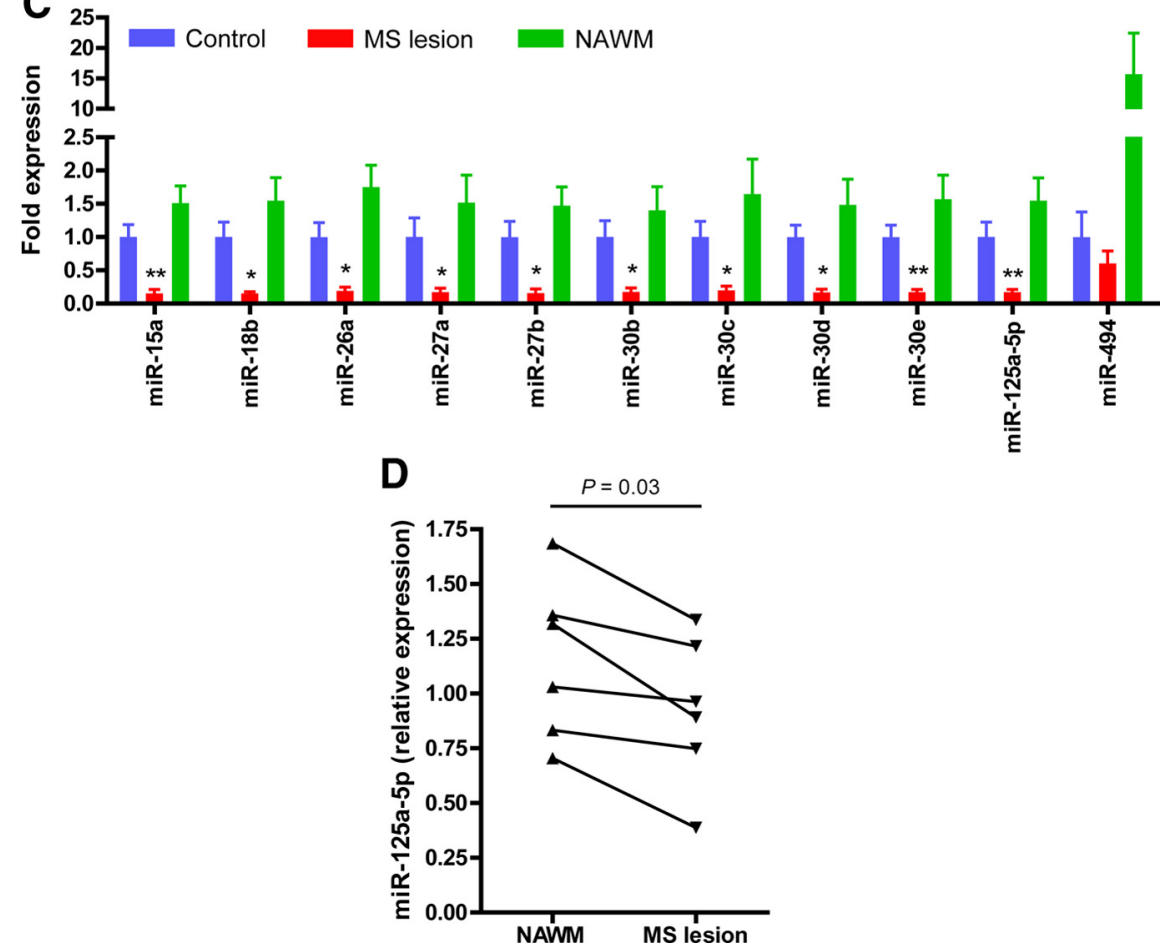
A

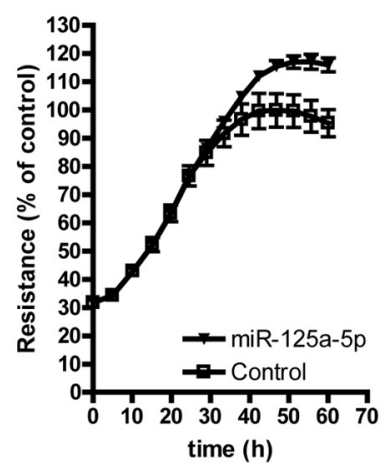

C
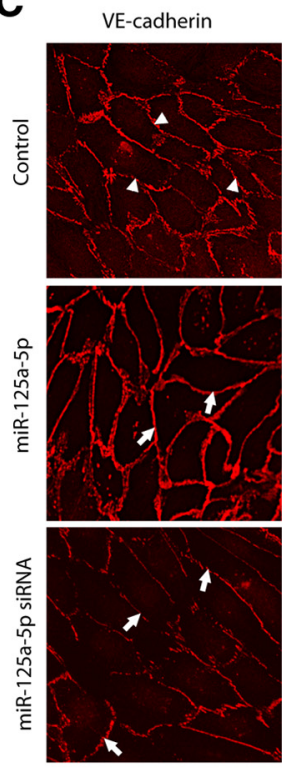

D

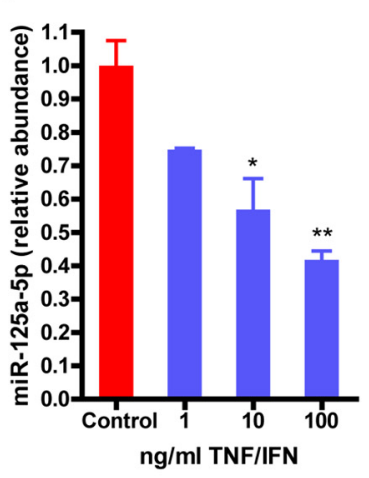

E
B

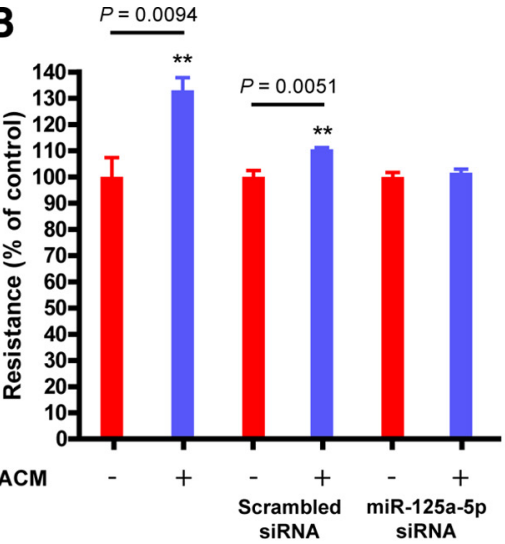

ZO-1
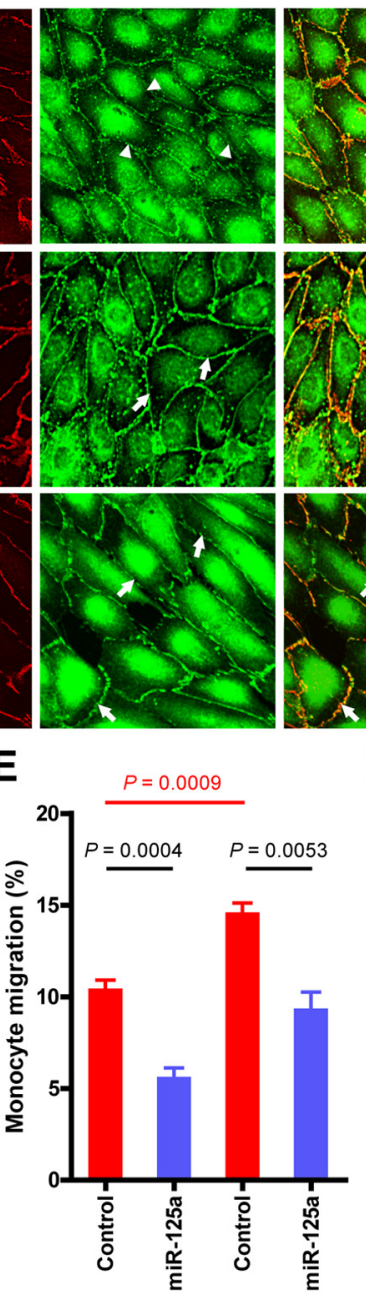

$\overline{-\mathrm{TNF}} \alpha \quad \overline{+\mathrm{TNF}} \alpha$ merge
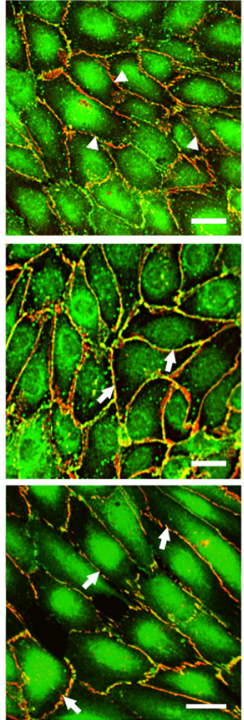

$\mathbf{F}$

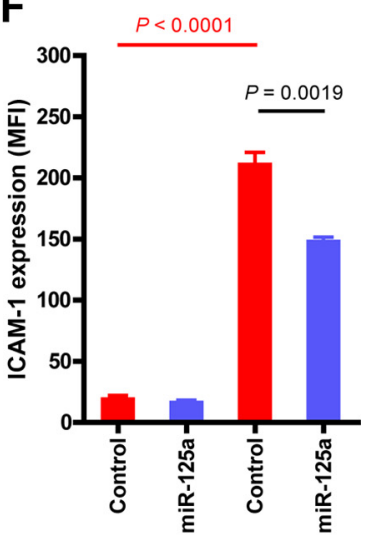

$\overline{-T N F} \alpha \quad \overline{T N F} \alpha$

Figure 3. Brain endothelial miR-125a-5p regulates barrier tightness and prevents leukocyte passage. $A, B, 0$ verexpression $(\boldsymbol{A})$ and knockdown $(\boldsymbol{B})$ of miR-125a-5p in hCMEC/D3 cells significantly modulates barrier tightness in control $(\boldsymbol{A})$ and ACM-treated cells $(\boldsymbol{B})$ as determined by ECIS (control: $809.3 \pm 48.9 \Omega$; miR-125a-5p: $948.5 \pm 18.7 \Omega$ ). $C$, VE-cadherin and zona occludens1(Z0-1) subcellular distribution in control cells, in miR-125a-5p-overexpressing hCMEC/D3 cells, and in miR-125a-5p-knockdown hCMEC/D3 cells. Scale bars, $25 \mu \mathrm{m}$. D. TNF $\alpha$ treatment of hCMEC/D3 decreases the expression of miR-125a-5p as measured by qPCR. Data show the abundance of miR-125a-5p normalized to the small nuclear RNA U6 relative to levels in control cells \pm SEM, $n=3,{ }^{*} p<0.05,{ }^{* *} p<0.005$ by Student's $t$ test. $\boldsymbol{E}$, Transendothelial migration of monocytes was studied in control hCMEC/D3 cells and in cells with enhanced expression miR-125a-5p previously treated or not with TNF $\alpha$. Data are expressed as the percentage of transmigrated monocytes and show the mean \pm SEM. $\boldsymbol{F}$, ICAM-1 expression in control hCMEC/D3 cells and in cells with enhanced expression of miR-125a-5p in the presence or absence of TNF $\alpha$ as measured by flow cytometry. Data are expressed as the mean fluorescence intensity and show the mean \pm SEM.

tral in the regulation of the balance between a tight and leaky BBB.

In our study, the expression of miR$125 \mathrm{a}-5 \mathrm{p}$ and many other microRNAs were regulated in human brain endothelial cells exposed to astrocyte factors. Importantly, brain capillaries are surrounded by and closely associated with the perivascular endfeet of astrocytes and there is now strong evidence that astrocytes can induce many $\mathrm{BBB}$ features, leading to tighter junctions (physical barrier), the expression and localization of specific transporters, including P-glycoprotein and glucose transporter-1 (transport barrier), and specialized metabolic systems (metabolic barrier; see review by Abbott et al., 2010). Astrocytes are able to secrete a range of agents (Abbott et al., 2006) and different research groups have attempted to identify these soluble factors, which may be responsible for the induction of BBB properties in cultured brain endothelial cells. Several of these astrocytederived factors, including transforming growth factor- $\beta$ (Garcia et al., 2004), glial-derived neurotrophic factor (Igarashi et al., 1999), angiotensin II (Wosik et al., 2007), and angiopoietin 1 (Lee et al., 2003) can induce different aspects of the BBB phenotype in endothelial cells in vitro. More recently, using a shotgun proteomics and bioinformatics approach, others have identified and classified the proteins present in conditioned media of cultured astrocytes (Dowell et al., 2009). Future analyses are warranted to identify the soluble factors that mediate microRNA responses in brain endothelial cells.

Altogether, our data provide compelling evidence pointing to an important function for microRNAs at the BBB, in particular during inflammation. In the field of brain diseases, microRNAs are rapidly moving to center stage as key regulators of neuronal development and function as well as important contributors to neurodegeneration (Hébert and De Strooper, 2009; De Smaele et al., 2010). As such, the functionality of microRNA in MS is still largely unexplored. The first findings in this area are, however, exciting. Recent studies have revealed that microRNA profiles in peripheral blood cells become altered in MS, and that active and inactive MS lesions have distinct microRNA expression patterns (Du et al., 2009; Junker et al., 2009, 2011). The deregulated microRNAs in MS lesions seem to be associated with immune responses, and might unleash local macrophages through downregulation of the selfrecognition signal CD47(Junker et al., 
2009). Such findings indicate that MS is the effect of (auto)immune responses mediated, at least partially, by microRNAs. In 2010, a study published in Nature (Du et al., 2009) showed that the expression of a TH-17 cell-associated microRNA, miR-326, is highly correlated with disease severity in patients with MS and in mice with experimental autoimmune encephalomyelitis, a model for brain inflammation widely used to study CNS demyelinating diseases, such as MS.

Although the mechanism of action and specific mRNA targets of miR-125a-5p are largely unknown, others have shown that miR-125a-5p has a role in different tumor types and inflammation. miR-125a-5p is decreased in non-small cell lung cancer (Jiang et al., 2010), hepatocellular carcinoma (Murakami et al., 2006), breast cancer (Guo et al., 2009), and medulloblastoma (Ferretti et al., 2009). Low expression levels of miR-125a-5p were associated with enhanced malignant potential of gastric cancer, possibly through repression of ERBB2, leading to reduced extracellular-signal regulated kinase $1 / 2$ and Akt signaling (Scott et al., 2007; Nishida et al., 2011). Other cancer-related mRNA targets of miR-125a-5p are TrkC (Ferretti et al., 2009), the oncogene p53 (Zhang et al., 2009), human antigen R (Guo et al., 2009), and cyclin-dependent kinase inhibitor 1A (Wu et al., 2010). Although microRNAs have received increasing attention as regulators that fine-tune the inflammatory response, much less is known about the function of miR-125a-5p in inflammatory processes. It is of interest that miR-125a-5p inhibits endothelin-1 expression in vascular endothelial cells (Li et al., 2010). Endothelin-1 is a proinflammatory protein involved in monocyte diapedesis (Reijerkerk et al., 2012). Others previously showed that miR-125a decreases the secretion of some inflammatory cytokines (IL-2, IL- 6 , TNF- $\alpha$, and TGF- $\beta$ ) by targeting the oxysterol binding protein-like 9 (Chen et al., 2009). Moreover, miR125 a contributed to elevated inflammatory chemokine RANTES (regulated on activation, normal T-cell expressed and secreted) levels via targeting of KLF13 in systemic lupus erythematosus (Zhao et al., 2010). The mechanism of action of miR-125a-5p in the inflamed BBB warrants further study. Finally, deregulation of microRNAs contributes to many human diseases and there is great interest in microRNAs as novel therapeutic targets or tools. The direction toward therapeutic application has been set in animal models to suppress liver cancer (Hébert and De Strooper, 2009) or chronic hepatitis C virus infection (Kota et al., 2009). Importantly, our current data point to a significant and novel role of microRNAs in BBB functioning. Many neurological disorders are associated with profound alterations in the vasculature of the brain. Therapeutic application of microRNAs, such as miR-125a$5 \mathrm{p}$, potentially could re-establish normal functioning of the brain vasculature in endothelial cell-based neurological diseases, in particular MS.

\section{References}

Abbott NJ, Ronnbäck L, Hansson E (2006) Astrocyte-endothelial interactions at the blood-brain barrier. Nat Rev Neurosci 7:41-53. CrossRef Medline

Abbott NJ, Patabendige AA, Dolman DE, Yusof SR, Begley DJ, et al. (2010) Structure and function of the blood-brain barrier. Neurobiol Dis 37:13-25. CrossRef Medline

Alvarez JI, Dodelet-Devillers A, Kebir H, Ifergan I, Fabre PJ, Terouz S, Sabbagh M, Wosik K, Bourbonnière L, Bernard M, van Horssen J, de Vries HE, Charron F, Prat A, et al. (2011) The Hedgehog pathway promotes blood-brain barrier integrity and CNS immune quiescence. Science 334: 1727-1731. CrossRef Medline

Baldi P, Long AD (2001) A Bayesian framework for the analysis of microarray expression data: regularized $t$-test and statistical inferences of gene changes. Bioinformatics 17:509-519. CrossRef Medline
Benjamini Y, Hochberg Y (1995) Controlling the false discovery rate: a practical and powerful approach to multiple testing. J R Stat Soc 57:289-300.

Bonauer A, Boon RA, Dimmeler S (2010) Vascular microRNAs. Curr Drug Targets 11:943-949. CrossRef Medline

Chen T, Huang Z, Wang L, Wang Y, Wu F, Meng S, Wang C, et al. (2009) MicroRNA-125a-5p partly regulates the inflammatory response, lipid uptake, and ORP9 expression in oxLDL-stimulated monocyte/macrophages. Cardiovasc Res 83:131-139. CrossRef Medline

Daneman R, Zhou L, Kebede AA, Barres BA, et al. (2010) Pericytes are required for blood-brain barrier integrity during embryogenesis. Nature 468:562-566. CrossRef Medline

De Smaele E, Ferretti E, Gulino A (2010) MicroRNAs as biomarkers for CNS cancer and other disorders. Brain Res 1338:100-111. CrossRef Medline

Dowell JA, Johnson JA, Li L (2009) Identification of astrocyte secreted proteins with a combination of shotgun proteomics and bioinformatics. J Proteome Res 8:4135-4143. CrossRef Medline

Du C, Liu C, Kang J, Zhao G, Ye Z, Huang S, Li Z, Wu Z, Pei G, et al. (2009) MicroRNA miR-326 regulates TH-17 differentiation and is associated with the pathogenesis of multiple sclerosis. Nat Immunol 10:1252-1259. CrossRef Medline

Ferretti E, De Smaele E, Po A, Di Marcotullio L, Tosi E, Espinola MS, Di Rocco C, Riccardi R, Giangaspero F, Farcomeni A, Nofroni I, Laneve P, Gioia U, Caffarelli E, Bozzoni I, Screpanti I, Gulino A, et al. (2009) MicroRNA profiling in human medulloblastoma. Int J Cancer 124:568-577. CrossRef Medline

Filipowicz W, Bhattacharyya SN, Sonenberg N (2008) Mechanisms of posttranscriptional regulation by microRNAs: are the answers in sight? Nat Rev Genet 9:102-114. Medline

Garcia CM, Darland DC, Massingham LJ, D'Amore PA, et al. (2004) Endothelial cell-astrocyte interactions and TGF beta are required for induction of blood-neural barrier properties. Brain Res Dev Brain Res 152:25-38. CrossRef Medline

Guo X, Wu Y, Hartley RS (2009) MicroRNA-125a represses cell growth by targeting HuR in breast cancer. RNA Biol 6:575-583. CrossRef Medline

Hébert SS, De Strooper B (2009) Alterations of the microRNA network cause neurodegenerative disease. Trends Neurosci 32:199-206. CrossRef Medline

Igarashi Y, Utsumi H, Chiba H, Yamada-Sasamori Y, Tobioka H, Kamimura Y, Furuuchi K, Kokai Y, Nakagawa T, Mori M, Sawada N, et al. (1999) Glial cell line-derived neurotrophic factor induces barrier function of endothelial cells forming the blood-brain barrier. Biochem Biophys Res Commun 261:108-112. CrossRef Medline

Jiang L, Huang Q, Zhang S, Zhang Q, Chang J, Qiu X, Wang E, et al. (2010) Hsa-miR-125a-3p and hsa-miR-125a-5p are downregulated in non-small cell lung cancer and have inverse effects on invasion and migration of lung cancer cells. BMC Cancer 10:318. CrossRef Medline

Junker A, Krumbholz M, Eisele S, Mohan H, Augstein F, Bittner R, Lassmann H, Wekerle H, Hohlfeld R, Meinl E, et al. (2009) MicroRNA profiling of multiple sclerosis lesions identifies modulators of the regulatory protein CD47. Brain 132:3342-3352. CrossRef Medline

Junker A, Hohlfeld R, Meinl E (2011) The emerging role of microRNAs in multiple sclerosis. Nat Rev Neurol 7:56-59. CrossRef Medline

Keese CR, Wegener J, Walker SR, Giaever I, et al. (2004) Electrical woundhealing assay for cells in vitro. Proc Natl Acad Sci U S A 101:1554-1559. CrossRef Medline

Kota J, Chivukula RR, O’Donnell KA, Wentzel EA, Montgomery CL, Hwang HW, Chang TC, Vivekanandan P, Torbenson M, Clark KR, Mendell JR, Mendell JT, et al. (2009) Therapeutic microRNA delivery suppresses tumorigenesis in a murine liver cancer model. Cell 137:1005-1017. CrossRef Medline

Larochelle C, Alvarez JI, Prat A (2011) How do immune cells overcome the blood-brain barrier in multiple sclerosis? FEBS Lett 585:3770-3780. CrossRef Medline

Lassmann H, Brück W, Lucchinetti CF (2007) The immunopathology of multiple sclerosis: an overview. Brain Pathol 17:210-218. CrossRef Medline

Lee SW, Kim WJ, Choi YK, Song HS, Son MJ, Gelman IH, Kim YJ, Kim KW, et al. (2003) SSeCKS regulates angiogenesis and tight junction formation in blood-brain barrier. Nat Med 9:900-906. CrossRef Medline

Li D, Yang P, Xiong Q, Song X, Yang X, Liu L, Yuan W, Rui YC, et al. (2010) 
MicroRNA-125a/b-5p inhibits endothelin-1 expression in vascular endothelial cells. J Hypertens 28:1646-1654. CrossRef Medline

Murakami Y, Yasuda T, Saigo K, Urashima T, Toyoda H, Okanoue T, Shimotohno K, et al. (2006) Comprehensive analysis of microRNA expression patterns in hepatocellular carcinoma and non-tumorous tissues. Oncogene 25:2537-2545. CrossRef Medline

Neuwelt EA, Bauer B, Fahlke C, Fricker G, Iadecola C, Janigro D, Leybaert L, Molnár Z, O'Donnell ME, Povlishock JT, Saunders NR, Sharp F, Stanimirovic D, Watts RJ, Drewes LR, et al. (2011) Engaging neuroscience to advance translational research in brain barrier biology. Nat Rev Neurosci 12:169-182. CrossRef Medline

Neuwelt E, Abbott NJ, Abrey L, Banks WA, Blakley B, Davis T, Engelhardt B, Grammas P, Nedergaard M, Nutt J, Pardridge W, Rosenberg GA, Smith Q, Drewes LR, et al. (2008) Strategies to advance translational research into brain barriers. Lancet Neurol 7:84-96. CrossRef Medline

Nishida N, Mimori K, Fabbri M, Yokobori T, Sudo T, Tanaka F, Shibata K, Ishii H, Doki Y, Mori M, et al. (2011) MicroRNA-125a-5p is an independent prognostic factor in gastric cancer and inhibits the proliferation of human gastric cancer cells in combination with trastuzumab. Clin Cancer Res 17:2725-2733. Medline

O'Connell RM, Kahn D, Gibson WS, Round JL, Scholz RL, Chaudhuri AA, Kahn ME, Rao DS, Baltimore D, et al. (2010) MicroRNA-155 promotes autoimmune inflammation by enhancing inflammatory T cell development. Immunity 33:607-619. CrossRef Medline

Reijerkerk A, Lakeman KA, Drexhage JA van Het Hof B, van Wijck Y, van der Pol SM, Kooij G, Geerts D, de Vries HE, et al. (2012) Brain endothelial barrier passage by monocytes is controlled by the endothelin system. J Neurochem 121:730-737. CrossRef Medline

Scott GK, Goga A, Bhaumik D, Berger CE, Sullivan CS, Benz CC, et al. (2007) Coordinate suppression of ERBB2 and ERBB3 by enforced expression of micro-RNA miR-125a or miR-125b. J Biol Chem 282:1479-1486. Medline

Smits M, Wurdinger T, Van het Hof B, van het Hof B, Drexhage JA, Geerts D, Wesseling P, Noske DP, Vandertop WP, de Vries HE, Reijerkerk A, et al.
(2012) Myc-associated zinc finger protein (MAZ) is regulated by miR$125 \mathrm{~b}$ and mediates VEGF-induced angiogenesis in glioblastoma. FASEB J 26:2639-2647. CrossRef Medline

Suárez Y, Sessa WC (2009) MicroRNAs as novel regulators of angiogenesis. Circ Res 104:442-454. CrossRef Medline

Voorhoeve PM, le Sage C, Schrier M, Gillis AJ, Stoop H, Nagel R, Liu YP, van Duijse J, Drost J, Griekspoor A, Zlotorynski E, Yabuta N, De Vita G, Nojima H, Looijenga LH, Agami R, et al. (2006) A genetic screen implicates miRNA-372 and miRNA-373 as oncogenes in testicular germ cell tumors. Cell 124:1169-1181. CrossRef Medline

Weksler BB, Subileau EA, Perrière N, Charneau P, Holloway K, Leveque M, Tricoire-Leignel H, Nicotra A, Bourdoulous S, Turowski P, Male DK, Roux F, Greenwood J, Romero IA, Couraud PO, et al. (2005) Bloodbrain barrier-specific properties of a human adult brain endothelial cell line. FASEB J 19:1872-1874. Medline

Wosik K, Cayrol R, Dodelet-Devillers A, Berthelet F, Bernard M, Moumdjian R, Bouthillier A, Reudelhuber TL, Prat A, et al. (2007) Angiotensin II controls occludin function and is required for blood brain barrier maintenance: relevance to multiple sclerosis. J Neurosci 27:9032-9042. CrossRef Medline

Wu S, Huang S, Ding J, Zhao Y, Liang L, Liu T, Zhan R, He X, et al. (2010) Multiple microRNAs modulate p21Cip1/Waf1 expression by directly targeting its $3^{\prime}$ untranslated region. Oncogene 29:2302-2308. CrossRef Medline

Zhang Y, Gao JS, Tang X, Tucker LD, Quesenberry P, Rigoutsos I, Ramratnam B, et al. (2009) MicroRNA 125a and its regulation of the p53 tumor suppressor gene. FEBS Lett 583:3725-3730. CrossRef Medline

Zhao X, Tang Y, Qu B, Cui H, Wang S, Wang L, Luo X, Huang X, Li J, Chen S, Shen N, et al. (2010) MicroRNA-125a contributes to elevated inflammatory chemokine RANTES levels via targeting KLF13 in systemic lupus erythematosus. Arthritis Rheum 62:3425-3435. CrossRef Medline

Zlokovic BV (2008) The blood-brain barrier in health and chronic neurodegenerative disorders. Neuron 57:178-201. CrossRef Medline 